\begin{tabular}{c} 
Volume and Issues Obtainable at Center for Sustainability Research and Consultancy \\
Journal of Business and Social Review in Emerging Economies \\
ISSN: 2519-089X (E): 2519-0326 \\
Volume 6: No. 1, March 2020 \\
CSRᄃ \\
Journal homepage: www.publishing.globalcsrc.org/jbsee \\
\hline
\end{tabular}

\title{
Impact of Status Consciousness on Consumer Purchase Intention and Brand Equity: the Mediating Role of Brand Associations
}

\author{
${ }^{1}$ Hayat M. Awan, ${ }^{2}$ Zara Hayat, ${ }^{3}$ Sahar Hayat, ${ }^{4}$ Rafia Faiz \\ ${ }^{1}$ Air University Multan Campus, Pakistan: hma@aumc.edu.pk \\ ${ }^{2}$ Bahauddin Zakariya University Multan, Pakistan \\ ${ }^{3}$ NFC-IET, Multan, Pakistan \\ ${ }^{4}$ IBA, University of Punjab, Lahore, Pakistan
}

\begin{tabular}{l} 
ARTICLE DETAILS \\
\hline History \\
Revised format: February 2020 \\
Available Online: March 2020
\end{tabular}

Status Consciousness,

Consumer, Brand Equity,

Purchase Intention

\section{JEL Classification:}

D0, D6, D7

OPEN
Keywords

\section{ABSTRACT}

This paper studies the impact of status consciousness on consumer's purchase intention and brand equity. It also examines the mediating role of brand associations between status consciousness, purchase intention and brand equity. A self-administered questionnaire was developed and data was collected from a sample of 500 female customers. The results support that status conscious consumers develop associations towards the brands and so they intend to purchase those brands, thus raising the brand equity. The results obtained will help the marketers by focusing on developing strong brand associations for luxurious brands for the status conscious consumers. It will also help in developing marketing strategies specifically designed to promote luxurious brands to increase consumer's purchase intention and brand equity.

(C) 2020 The authors, under a Creative Commons AttributionNonCommercial 4.0

Corresponding author's email address: hma@aumc.edu.pk

Recommended citation: Awan, H. M., Hayat, Z., Hayat, S. \& Faiz, R., (2020). Impact of Status Consciousness on Consumer Purchase Intention and Brand Equity: the Mediating Role of Brand Associations. Journal of Business and Social Review in Emerging Economies, 6(1), 23-42

DOI: $10.26710 /$ jbsee.v6i1.1023

\section{Introduction}

The impact In the field of marketing, branding is of greater importance. Large number of companies are striving hard and developing strategies to create brand that can generate value both for the firm and the customers. This is because of the quick change in the worldwide market and rise of rivalry among firms. This change leads to an understanding of effective brand management. Through clear product differentiation and focus on consumer preferences, a rise in market share occurs. That's why companies are working hard to differentiate their brands from others as this differentiation leads to creating a special brand image in the mind of the customer due to which customers can recognize that brand on the basis of the prior knowledge they have in their minds about that brand. This differentiation is also very important because in today's world where there are unlimited brands, there is a need to create unique position of a brand in consumers mind as Lim and O'Cass (2001) indicated that the most valuable assets and sources of differentiation for firms are their brands. Also this has an impact on consumer's brand selection and 
purchase intention and ultimately this will lead to an increase in brand equity which will affect firm's profits as brands are the important contributors in the profits of firms. Also they are huge investments as Pitta and Katsanis (1995) stated that to bring a new brand in market costs around 50 million dollars. That is why to build a strong perception of brand is of prime importance for many firms today (Morris, 1996).

Creating strong and effective brand management is linked to understanding the consumer behavior. Consumer's purchase behavior is backed by many factors. It is extremely important to understand how consumers perceive information and on what psychological factors they make their decisions. Also it is important to understand that how consumers evaluate different brands and how this evaluation leads to brand selection and purchase. In this regard, one very important motivational factor is the "need for status in consumers" that has emerged as a strong motivator which leads to the selection of status brands and their purchase (Eastman et al., 1999).

With the changing life styles and economies, luxury consumption is increasing and also there is a positive relation between economic growth and increased spending on luxuries (Eng and Bogaert, 2010). While the research is going on status seeking behavior and status consumption, there is still a call for more research on desire for status in people and their consumption patterns as understanding the human needs and their motivation for consumption is very important for the firms to attract and gain status seeking consumers and to create brands with symbolic significance. Status conscious people pay more attention to brands as compared to others brands. They spend a lot of their money on purchasing these brands. And they prefer those brands that reflect their personalities (Goldsmith, Flynn and Clark, 2012) and on the basis of this they develop associations towards brands and want to get associated with brands that are considered status laden brands in society (O'Cass and Frost, 2002). In this regard, fashion clothing brands are gaining prime importance as fashion clothing is socially and economically important in many societies (Michealdious and Dibb, 2006; O'Cass, 2004; Aunty and Elliot, 1998). Literature explains that clothing of an individual tells the importance of an individual and through fashion clothing people communicate status and symbolically display their identities in the society (O'Cass and Frost, 2002; Han et al., 2010; O'Cass, 2000). For this reason many clothing brands around the world are putting their efforts to bring creative and unique fashion clothing to create a large customer range. In Pakistan in the recent years Eastern branded lawn has become a premium brand among females and they want to get associated with these brands to increase their status and communicate their wealth to others. In this regard, this paper aims to understand the need for status in people and its relation with brand associations and its impact on brand equity and consumer purchase intention. Also this study aims to examine the mediating role of brand associations.

As a contextual contribution, this paper focuses on the buying pattern of female customers of eastern branded lawn in Pakistan and their need for status. In case of Pakistan, where this eastern branded lawn has become a premium brand there is hardly any research which has studied this need for status in female customers in eastern branded lawn industry.

\section{Literature review and Hypotheses Development \\ 2.1 Status Consciousness}

Many researchers have studied the need for status in consumers and their consumption behavior towards luxury items (Eastman et al., 1999; O'Cass and Frost, 2002; Eastman and Eastman, 2011; Husic and Cicic, 2009; O'Cass and Vida, 2014; Wong and Ahuvia, 1998; O'Cass and MaEwan, 2004). Packard (1959) defined "Status seekers" as people who are continually straining to surround themselves with visible evidence of the superior rank they are claiming". People want to gain "status" which is defined as a "individual's hierarchy within a group based on the prestige, honor and difference accorded to them by others"(Burn, 2004), that is considered important by society, and they want prestigious position by consuming goods that are regarded as high in status by others (O'Cass and Frost, 2002). Status consciousness is defined as "a mode of being" (O'Cass and Siahtiri, 2012). Status conscious consumers are those who gain their social standing by consuming products that communicate status and for this they 
get involved in status consumption ( O’Cass and Frost, 2002, Clark et al., 2006, Wong and Ahuvia, 1998). Status consumption is defined as "a motivational process by which individual strives to improve social standing through the conspicuous consumption of consumer products that confer and symbolize status both for the individual and surrounding significant others (Kilsheimer,1 993; Eastman, Goldsmith and Flynn, 1999). Status consumptions is to show position (Gold smith, Flynn and Clark, 2012). Status conscious people develop their social image by consuming status goods (Clark et al., 2006, Wong and Ahuvia, 1998). Social image is defined as "the consumer's perception of the esteem in which the consumer's social group holds the brand" (Lassar, Mittal and Sharma, 1995). People own luxury items to show their superior social position and that's why people demand for products is based more on social factors than on utility factors (Veblen, 1899). This implies that people with high need for status will consume brands that are socially accepted as prestigious brands and carrying such brands will display the wealth of the consumer to others in society.

\subsection{Brand Associations}

To create knowledge about the brand in the mind of the customers is very important for the firms (Keller, 1993). Based on this many researchers have explained brand associations in literature. Aaker (1991, 1996) defined "brand associations as anything linked in the memory to a brand". Associative network model further explains it that the memory consists of a set of nodes and links. One node links to another node. If a consumer has some knowledge and is familiar with the brand that will link it to develop associations with that brand and each time when a consumer comes across that brand, can associate it based on the previous brand knowledge in consumer's mind. Also these associations if favorable, strong and unique will create positive brand image in the mind of the customers (Keller, 1993; Kamakura and Russell, 1991).

Brand associations are important as they strongly communicate knowledge about the product and through these people can recognize and differentiate between different brands. They also help consumers to get familiar with the brands. And if these associations are strong, people can get an image about the product and want to get associated with that product.

As status conscious people satisfy their need for status by displaying and consuming status goods (brands), (O'Cass and Frost, 2002; Clark et al., 2006; Wong and Ahuvia, 1998; Kilsheimer,1993; Eastman, Goldsmith and Flynn, 1999; Gabriel and Lang, 2006), they would prefer to get associated with those brands which can really display status (Gold smith, Flynn and Clark, 2012) and are accepted by society as status laden and prestigious products (Eastman et al., 1999).

Brand associations contain meaning of the brand for consumers and are stored in consumer's memory as the other informational node linked to the brand node (A. Belen del Rio et.al, 2001). Also consumer response differs towards the brands based on unique brand associations these brands hold (Keller, 1993). Lassar (1995) explained that consumer build their social image by becoming user of a particular brand to show esteem in their social group. This implies that when status conscious consumers consume status brands which are considered to be status symbols in the society, they will develop associations towards those brands and want to use these brands to communicate their wealth in the society (O'Cass and Frost, 2002). Status conscious people therefore pay more attention towards brands compared to others, give them more importance and can spend more money on acquiring brands that reflect their personalities (Goldsmith, Flynn and Clark, 2012).

\subsection{Brand Equity}

Aaker (1991) defined "brand equity" as a set of assets (and liabilities) linked to brand's name and symbol that adds to/or (subtract from) the value provided by a product or service to a firm and/or that firm's customers. Keller (1993) defined customer based brand equity as the differential effect of brand knowledge on consumer response to the marketing of the brand. This was based from customer's point of view. It can be seen in both the definitions that brand equity occurs when the brand provides value to both 
the firm and the firm's customers. Brand knowledge is in terms of associative network model which explains that the memory consists of a set of nodes and links. One node links to another node. When a consumer is aware of the brand, he will link it to that brand based on the associative network in consumer's memory. Lassar, Mittal and Sharma (1995) indicated that the perceptions about the product are the brand equity. Aaker(1991) further mentioned dimension of brand equity: brand loyalty, brand awareness, brand associations, perceived quality and other proprietary brand assets.

The above dimensions are important to build brand equity and if all of these are managed can lead to increase in brand equity. Keller's brand knowledge was consisted of two major components: brand awareness and brand image. Brand awareness plays a very important role as when a customer is willing to purchase a product the first name that comes to his mind is because of the awareness the customer has about that product (Malik et al., 2013). Also this impacts the purchase intention of consumer as indicated by Dodds, Monroe and Grewal (1991) that higher level of brand awareness impacts the purchase decisions of costumers. If a firm has strong and successful brand awareness this will lead to good repute of brand name in the market (Gustafson and Chabot, 2007). Also brand awareness creates brand association in the minds of customers about a particular brand (Stokes, 1985).

As status conscious consumers want to display wealth (Eastman et al., 1999) and they show off their prestigious social position by consuming luxurious brands (Goldsmith, Flynn and Clark, 2012) which are considered status symbols in the society (O'Cass and Frost, 2002) they will get interested in acquiring those status laden brands whose brand names and image are accepted very prestigious in their social group. By carrying these brands, they display their wealth to others. As Krishnan (1996) mentioned that high equity brands have greater associations as compared to low equity brands. So if brand seeker/ status seekers have knowledge about a certain brand which is considered as luxury brand in their social group they will intend to get that brand. Brand awareness creates brand knowledge through which consumer can recall the brand during the purchase decision. If a status conscious consumer knows about a particular brand as a status laden, high quality and high price brand, the customer can recall it during the purchase decision process (Malik et al., 2013) and if these brands satisfy their status needs they will develop association with those brands as O'Cass and Frost (2002) mentioned that status brands have more prestigious value in the minds of the customers. And the use of status brands fulfils one's need of displaying its status to others.

\subsection{Purchase Intention}

Consumer buying/purchase intention has got great attention in marketing literature (Warshaw, 1980; Kalwani and Silo, 1982; Smith and Swinyard, 1983; Bemmaor, 1995). Dodds et al., (1991) proposed purchase intention as "buying willingness". The purchase intention is also indicated as consumer's efforts for buying a product (Shao, Baker and Wagner, 2004).

The buying intention of a consumer towards any product depends on consumer's attitude and beliefs towards that particular product (Fishbein and Ajzen, 1975, 1980). Consumers attitudes impact their purchase decisions and attitudes are impacted by social groups, the one to which a consumer aspires to belong, the experience and personality (Espejel et al., 2008).

To gain social position or to show their uniqueness, status conscious consumers indulge in status goods consumption leading to associating with brands which are status symbols in society. This will motivate them to purchase status laden products. Literature explains that people get associated with the product/brand on the basis of certain associations they have in their mind. For example in case of status conscious people, if a consumer wants a product that is positioned in the mind as status laden and prestigious product, the status conscious person will go for purchasing it. As according to Pitta et al., (1995) when a person recognizes a problem or sees a product, a spreading process will start connecting a node to the other node and determines the extent of retrieval. Positive brand image and associations have a greater impact on brand choice (Keller, 1993). And also brand associations act a meaning of a brand for 
the consumers (A. Belen del Rio et al., 2001). This implies that status conscious people develop associations with the status products and this influences their purchase behavior.

Brand equity is considered to be consisted of consumer's brand associations including brand awareness, knowledge and image (Keller, 1991, 1993). The brand names also impact consumer's purchase intention. Brand name if positioned as premium brand in consumer's mind will impact the purchase decision. For example Michael Kors or Gucci wrist watches are considered to be luxurious in society so the status conscious people will intend to purchase such brands to display wealth as explained by Lassar, Mittal and Sharma, (1995) that brand name increase the desirability and utility of the product. Also Lassar, mittal and Sharma (1995) indicated that brand equity occurs when a consumer perceives a product superior to other brand because of the product's brand name.

Brand awareness is important as when a customer is going through a purchase decision process for a product the first name that comes to the mind is because of the awareness the customer has about that product (Malik et al., 2013). Also this impacts the purchase intention of consumer as indicated by Dodds, Monroe and Grewal (1991) that the greater the level of brand awareness, the higher will be the chances that the customer will go for the purchase of that brand. With the increase in brand associations the purchase intention of consumers increases towards brands because brand associations help the consumers to recall the brand based on the link node of that brand which they have in their mind (Park and Shrinivavan, 1994; Cobb Walgren et al., 1995; Agarwal and Rao, 1996; Yoo et al., 2000; O'Cass and Lim, 2002; O'Cass and Lim 2001). These brand associations create knowledge about the brand and on the basis of this the consumer response towards the brands differs (Keller, 1993). But research also explains that when brand name adds some value to a product leads to brand equity (Pitta et al., 1995) and consumers perceive brands and their marketing activities on the basis of which they develop brand image (Sjodin and Torn, 2006) and these perceptions help in building the brand equity (Lassar, Mittal and Sharma, 1995). The brand awareness created in the mind of customers develop the brand image and thus this study proposes that if the brand image is strong in consumer's mind and they are aware about that brand then this along with brand associations, will impact more on consumer purchase intention.

On the basis of the above arguments, following hypotheses are proposed:

H1: Status consciousness has a positive significant effect on brand associations

$\mathrm{H} 2$ : Brand associations have positive significant effect on purchase intention

H3: Brand associations have a positive significant effect on brand equity

H4: Brand associations mediate the relationship between status consciousness and purchase intention

H5: Brand associations mediate the relationship between status consciousness and brand equity

H6: Status consciousness has positive significant effect on purchase intention

H7: Status consciousness has positive significant effect on brand equity

H8: Brand equity has positive significant effect on purchase intention

H9: Brand equity mediates the relation between brand associations and purchase intention.

\section{Research Methodology}

This section entails the discussion of data collection and sampling procedures. It also elaborates about the measurement of constructs and description of data analysis techniques.

\subsection{Sample and Procedures}

There is an accelerated growth in fashion and apparel industry in Pakistan with the launch of larger number of eastern branded lawn in last ten years. . In fashion clothing, Eastern branded lawn has become a luxurious product in Pakistan with high prices and quality thus making it a premium product. This study is based on a survey in which data was collected from female customers who visit the outlets of eastern brands of lawn. The sample size of 500 respondents covers five major cities of Pakistan including Karachi, Lahore, Islamabad, Faisalabad and Multan. A survey questionnaire was used to collect the data. 
A self administered questionnaire was developed on a seven point likert scale ranging from "strongly agree" to "strongly disagree".

\subsection{Measures}

The measurement of constructs was adapted from previous studies using the seven-points Likert scales. In this study Status Consciousness scale was adapted from Eastman et al. 1999. Brand associations were measured from brand familiarity and brand symbolism. Brand familiarity scale was adapted from Flynn and Goldsmith (1999) and brand symbolism scale was adapted from Subodh Bhat Srinivas K. Reddy (1998). Purchase intention scale was adapted from Palmatier et al., 2009; Maxham, 2001. Brand equity scale was adapted from Lasser et al., 1995.

\subsection{Statistical Analysis and Techniques}

The hypothesized model of this study was tested using the structural equation modeling (SEM) approach supported by AMOS employing the maximum likelihood estimation method. The study followed the twostep approach suggested by Anderson and Gerbing (1988). The measurement model was evaluated before examining the structural model. Confirmatory factor analysis (CFA) was performed to establish the construct validity in the measurement model stage. After verifying construct validity, structural model was examined to test the hypotheses and model fit.

\section{Analysis and Results}

This section entails descriptive and inferential analysis of data. Moreover, it includes the interpretation of results and findings.

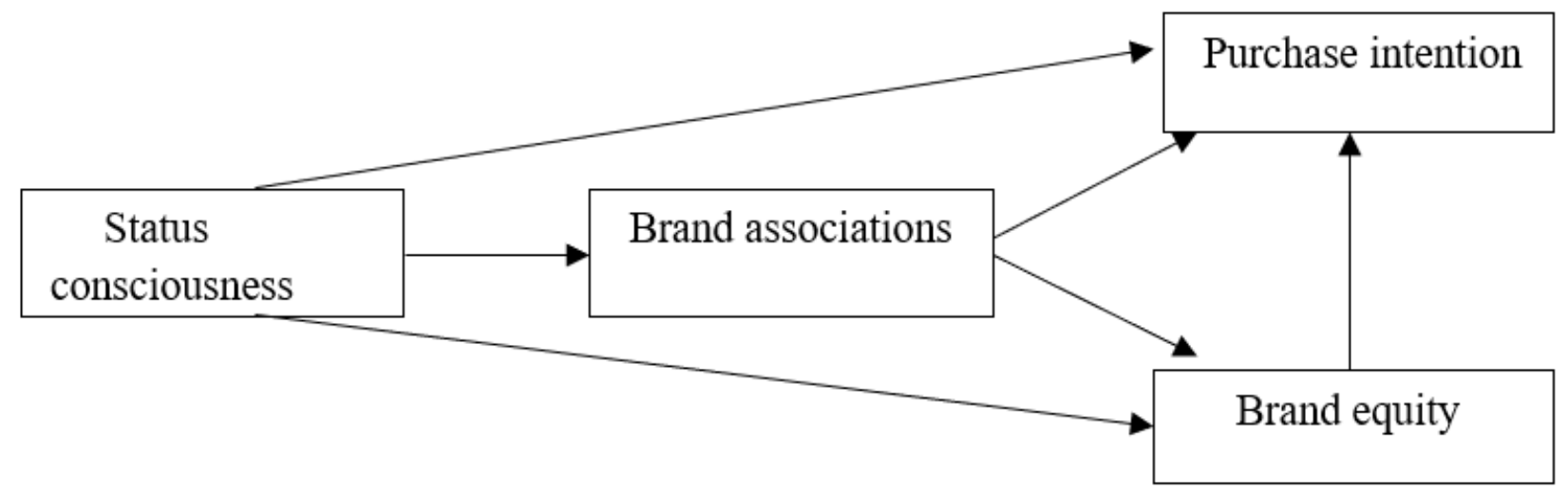

Figure1. Integrated framework on the effects of status consciousness on purchase intention and brand equity.

\subsection{The Measurement Model Results}

Confirmatory Factor Analysis (CFA) was applied to establish the construct validity in the measurement model stage. It helps to extract the factors and to eliminate the problematic items. Table (1) shows the extracted factors which are confirmed by CFA. The factor loadings for all the items were significant and exceeded minimum cut off value of 0.40 (SPSS 21). In addition, the results of internal reliability using Cronbach's alpha values ranged from 0.7 to 0.86 , higher than 0.70 as recommended by Nunnally and Bernstein (1994). Composite reliability value of all latent constructs is 0.755 which is closer to 1 and shows highly reliable research analysis. 
Table (1) Confirmatory Factor Analysis

\begin{tabular}{|c|c|c|c|c|}
\hline Factors & Items & $\begin{array}{l}\text { Factor } \\
\text { loadings }\end{array}$ & $\begin{array}{l}\text { Croan } \\
\text { bach's } \\
\text { Alpha }\end{array}$ & $\begin{array}{l}\text { Internal } \\
\text { Consistenc } \\
\mathrm{y}\end{array}$ \\
\hline $\begin{array}{l}\text { Status } \\
\text { consciousness }\end{array}$ & $\begin{array}{l}\text { I would buy a product just because it } \\
\text { has status } \\
\text { I am interested in new products with } \\
\text { status } \\
\text { I would pay more for a product if it } \\
\text { had status }\end{array}$ & $\begin{array}{l}.757 \\
.686 \\
.684\end{array}$ & .749 & Acceptable \\
\hline $\begin{array}{l}\text { Purchase } \\
\text { intention }\end{array}$ & $\begin{array}{l}\text { I would be very likely purchase some } \\
\text { dresses from this brand outlet } \\
\text { I would come back to this outlet of } \\
\text { branded lawn again } \\
\text { I will continue to purchase dresses } \\
\text { from this brand of lawn }\end{array}$ & $\begin{array}{l}.621 \\
.730 \\
.699\end{array}$ & .726 & Acceptable \\
\hline Brand equity & $\begin{array}{l}\text { The brand of lawn I am evaluating fits } \\
\text { my personality } \\
\text { The brand of lawn I am evaluating is } \\
\text { well regarded by my colleagues } \\
\text { I have positive personal feelings } \\
\text { toward the brand of lawn I am } \\
\text { evaluating }\end{array}$ & $\begin{array}{l}.655 \\
.610 \\
.633\end{array}$ & .667 & Acceptable \\
\hline $\begin{array}{l}\text { Brand } \\
\text { associations }\end{array}$ & $\begin{array}{l}\text { Among my circle of friends, I am an } \\
\text { 'expert' of the knowledge of branded } \\
\text { lawn } \\
\text { I have heard most of the new names of } \\
\text { the brands of lawn that are around } \\
\text { I can tell if the branded lawn clothe is } \\
\text { worth the price or not } \\
\text { People use branded lawn as a way of } \\
\text { expressing their } \\
\text { Unique-Ordinary personality } \\
\text { Stylish-Plain } \\
\text { Glamorous-Sedate }\end{array}$ & $\begin{array}{l}.782 \\
\\
.885 \\
.859 \\
.890 \\
\\
.406 \\
.440 \\
.457\end{array}$ & .863 & Good \\
\hline
\end{tabular}

Correlation analysis was applied using SPSS 21. The results in Table (2) show that the major contributor towards brand associations is status consciousness $(\mathrm{r}=0.213, \mathrm{p}=0.000)$. These results suggest that status consciousness impacts brand associations. Brand associations contain meaning of the brand for consumers and are stored in consumer's memory as the other informational node linked to the brand node (A. Belen del Rio et al., 2001). Lassar et al., 1995 explained that consumer build their social image by becoming user of a particular brand to show esteem in their social group. This implies that when status conscious 
consumers consume status brands which are considered to be status symbols in the society, they will develop associations towards those brands to communicate their wealth in their society. Status conscious people therefore pay more attention towards brands compared to others, give them more importance and can spend more money on acquiring brands that reflect their personalities and wealth.

The results show that the maximum contribution towards brand equity is coming from status consciousness $(r=0.370, p=0.000)$. These results suggest that status consciousness will impact brand equity. Research shows that status conscious people will go for acquiring those brands which are considered as status brand in society. As indicated by Keller (1993) that brand knowledge helps customers to differentiate between different brands and this brand knowledge and awareness impacts in consumer decision making process, so if a consumer has some knowledge and is familiar with the brand and has image about a brand as status brand and the brand's name is considered to be a highly prestigious in society then this will motivate them for the purchase of these brands (Eastman et al., 1999; O'Cass and Frost, 2002) thus increasing the brand equity.

The results show that the second major contributor towards brand equity is brand associations $(\mathrm{r}=0.278$, $\mathrm{p}=0.003$ ). These findings are in line with the findings of many other authors (e.g. Lassar et al., 1995; Cheng and Chen, 2001) who considered brand associations as the major contributor towards the brand equity. Brand associations create positive image in the mind of the customers and are stored as a link node in the consumer's memory. Brand associations also help in creating meaning for the consumers about a brand (Aaker, 19991). As Lassar et al., 1995 indicated that brand equity is the associations that the consumer holds about the brand thus leading to build a strong brand image.

The results show that maximum contribution towards purchase intention is coming from status consciousness $(\mathrm{r}=0.325, \mathrm{p}=0.000)$. These findings are in line with the findings of many other authors (e.g. Eastman et al., 1999; O'Cass and Frost, 2002; Clark et al., 2006). These findings suggest that status conscious people are more intended to purchase goods with status. The second major contributor towards purchase intention is the brand equity $(r=0.299, \mathrm{p}=0.007)$. the brand equity contributes towards purchase intention because when a consumer go through the purchase decision process then while evaluating the brands the consumer can differentiate between brands on the basis of the awareness, image, name and associations he is holding about the brand which will lead towards the purchase of that brand as also indicated by Dodds et al., (1991) that brand awareness impacts the purchase intention of the consumer. The third major contributor towards purchase intention is brand associations $(\mathrm{r}=0.209, \mathrm{p}=$ 0.000). These results suggest that as associations towards the brands get stronger there will more willingness to purchase those brands in consumers. These findings are in line with the findings of many researches which say that there is a positive relation between brand associations and purchase intention (Park and Shrinivavan, 1994; Cobb Walgren et.al, 1995; Agarwal and Rao, 1996 and Yoo et al., 2000; O'Cass and Lim, 2002; O'Cass and Lim 2001). People develop associations with brands and if these associations are strongly and uniquely positioned in their minds, they will recall that brand among other brands and this increases their probability to purchase that brand based on the image that was created by these associations in customer's mind.

Table (2) Correlation analysis

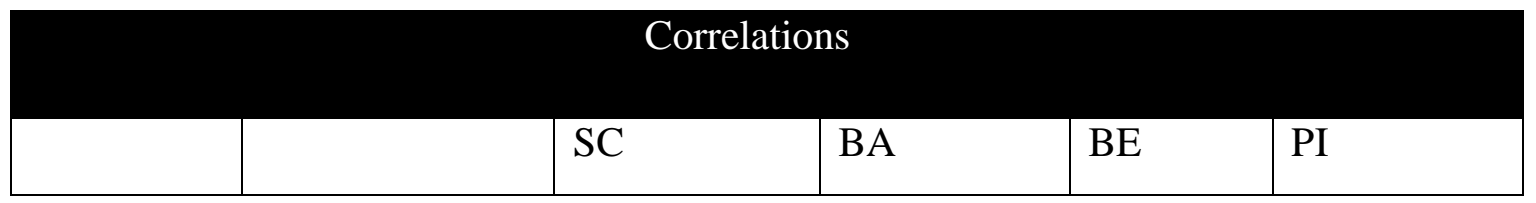




\begin{tabular}{|c|c|c|c|c|c|}
\hline $\mathrm{SC}$ & $\begin{array}{l}\text { Pearson } \\
\text { correlation } \\
\text { Sig. (2-tailed) } \\
\text { N }\end{array}$ & 500 & & & \\
\hline BA & $\begin{array}{l}\text { Pearson } \\
\text { correlation } \\
\text { Sig. (2-tailed) } \\
\text { N }\end{array}$ & $\begin{array}{r}.213 \\
\\
.000 \\
500\end{array}$ & 1 & & \\
\hline $\mathrm{BE}$ & $\begin{array}{l}\text { Pearson } \\
\text { correlation } \\
\text { Sig. (2-tailed) } \\
\text { N }\end{array}$ & $\begin{array}{r}.370 * * \\
.000 \\
500\end{array}$ & $\begin{array}{l}.278 \\
\\
.003 \\
500\end{array}$ & 1 & \\
\hline PI & $\begin{array}{l}\text { Pearson } \\
\text { correlation } \\
\text { Sig. (2-tailed) } \\
\text { N }\end{array}$ & $\begin{array}{l}.325 \\
\\
.000 \\
500\end{array}$ & $\begin{array}{r}.209 * * \\
.000 \\
500\end{array}$ & $\begin{array}{r}.299 * \\
.007 \\
500\end{array}$ & 1 \\
\hline
\end{tabular}

**. Correlation is significant at the 0.01 level (2-tailed).

Regression analysis was applied by using AMOS version 21. All the hypotheses $\mathrm{H} 1, \mathrm{H} 2, \mathrm{H} 3, \mathrm{H} 4, \mathrm{H} 7$ and H8 were supported with $\mathrm{p}<0.05$ as shown in table (3).

Results show that $\mathrm{H} 1$ has a $\mathrm{p}<0.05$ which shows that status consciousness has a significant effect on brand associations which means that when people become status conscious they develop associations towards the brands. These findings are in line with the findings of O'Cass and Frost, 2002. People with need for status want to gain high social and prestigious position in society. They seek for the products/brands which are unique. Brand associations are the link node in the mind of the customers (Aaker, 1991, 1993). The associations create image about the product in the mind of the customers. If a certain brand is associated with prestige and status will be positioned as high status brand in society. Status conscious people will acquire such brands and will differentiate them from others on the basis of the associations about that particular brand they hold in their mind.

Results also support $\mathrm{H} 2$ with $\mathrm{P}<0.05$ showing that brand associations have positive significant effect on purchase intention. These findings are in line with the findings of many other authors (Park and Shrinivavan, 1994; Cobb Walgren et al., 1995; Agarwal and Rao, 1996 and Yoo et al., 2000; O'Cass and Lim, 2001; O'Cass and Lim 2002). Brand associations develop image about the product and convey meaning o the customers. Brand associations help customers in getting familiar with the product and help in reducing customer's effort in brand evaluation and buying decision thus helping in gaining confidence on the product based on the knowledge being created in the mind. H3 is "Brand associations have positive significant effect on brand equity". H3 with $\mathrm{p}=0.058$ was weakly supported. The brand equity occurs when consumers make associations with the brand (Cheng and Chen, 2001). Brand associations if strong, favorable and unique create positive image about the brand. They convey knowledge about the brand and they are the associations that a consumer holds about the brand. Brand associations help in creating 
particular unique link node in the mind of the customer about the brand on the basis of which a customer can recognize the brand and can differentiate it among other brands.

H6 was also supported by the results with $\mathrm{p}<0.05$ which shows that status consciousness has positive significant effect on brand equity. Status conscious people want to get prestigious for which they indulge in status consumption. They seek brands which are considered highly prestigious brands in society and have got high brand name and prestigious position in the mind of the customers. The female users of branded lawn also seek brands that are positioned as highly prestigious brands in their minds. Branded lawn manufacturers are positing their brands through advertisements that their branded is high quality premium brand which is a status symbol in society. So female customers of these branded lawns are wearing these brands to satisfy their status needs.

Results also support $\mathrm{H} 7$ with $\mathrm{p}<0.05$ which shows that there is a positive relationship between status consciousness and purchase intention i.e. when people become status conscious their intention to purchase luxurious products increases. The people with need for status want to acquire those products which are status laden and through which they can show their wealth to others. For this they indulge in status consumption and are willing to purchase status laden products. As the results indicate that female customers who visit the branded lawn outlets are willing to purchase products from their outlets. They are motivated to purchase these branded lawns so that they can signal their wealth to others by wearing and consuming that premium brands.

H8 is also supported by the results with $\mathrm{p}<0.05$ which shows that brand equity has a positive effect on purchase intention i.e. when people will get to know what they want through brand awareness they will intend to purchase that brand. Brand equity is based on brand awareness and brand associations and the brand association create knowledge about the brand and thus communicate meaning of the brand to the customers. In eastern branded lawn sector in Pakistan, brands hugely invest on advertisements through which they build their image and unique position of their brands in the mind of the customers. They position them as unique and premium brands. Status conscious females on the basis of these advertisements get to know about their different brands and based on this they get an image of the brand and if it is positioned as premium brand they will intend to purchase that brand to satisfy their need for status.

Table (3) Regression analysis:

\begin{tabular}{|l|l|l|l|l|l|l|}
\hline Hypotheses & Estimates & S.E & C.R & $\begin{array}{c}\text { P } \\
\text { Value }\end{array}$ & Results \\
\hline $\begin{array}{l}\text { Status consciousness has a } \\
\text { positive significant effect } \\
\text { on Brand associations }\end{array}$ & $\mathrm{H} 1$ & .214 & .450 & 5.283 & $* * *$ & Supported \\
\hline $\begin{array}{l}\text { Brand associations have } \\
\text { positive significant effect } \\
\text { on Purchase intention }\end{array}$ & $\mathrm{H} 2$ & .212 & .443 & 4.983 & $* * *$ & Supported \\
\hline
\end{tabular}




\begin{tabular}{|c|c|c|c|c|c|c|}
\hline $\begin{array}{l}\text { Brand associations have a } \\
\text { positive significant effect } \\
\text { on brand equity }\end{array}$ & $\mathrm{H} 3$ & .141 & .223 & 1.761 & .058 & Supported \\
\hline $\begin{array}{l}\text { Status consciousness has } \\
\text { positive significant effect } \\
\text { on purchase intention }\end{array}$ & H6 & .375 & .451 & 7.113 & $* * *$ & Supported \\
\hline $\begin{array}{l}\text { Status consciousness has } \\
\text { positive significant effect } \\
\text { on brand equity }\end{array}$ & H7 & .229 & .326 & 8.894 & **** & Supported \\
\hline $\begin{array}{l}\text { Brand equity has a positive } \\
\text { significant effect on } \\
\text { purchase intention }\end{array}$ & $\mathrm{H} 8$ & .170 & . 282 & 2.066 & .039 & Supported \\
\hline
\end{tabular}

\subsection{Model Fit}

The goodness of fit indexes are shown in table (4). The value of chi- square is 2.173 which is greater than the threshold value of 0.05 . the value of GFI is 0.987 greater than threshold value of 0.90 , AGFI is 0.998 greater than 0.90 , RMSE is 0.154 less than 0.08 , RMR is 0.022 which is less than 0.08 , IFI is 0.932 , NFI is 0.988 , CFI is 0.933 and NFI is 0.990 , higher than 0.90 .

Table (4) Model Fit or proposed conceptual framework

\begin{tabular}{|c|c|c|c|}
\hline Author & Fitness Index & Required Value & Results \\
\hline (Hooper et al., 2008) & Chi-Square P-value & $>0.05$ & 2.173 \\
\hline (Schumacker \& Lomax, 2004) & CMIN/DF & $2.00-5.00$ & 2.070 \\
\hline (Byrne, 1998) & GFI & $>0.90$ & 0.987 \\
\hline
\end{tabular}




\begin{tabular}{|l|l|l|l|}
\hline (Byrne, 1998) & AGFI & $>0.90$ & 0.998 \\
\hline $\begin{array}{l}\text { (Browne, Cudeck, Bollen, \& Long, } \\
1993\end{array}$ & RMSE & $<0.08$ & 0.054 \\
\hline $\begin{array}{l}\text { (Hu \& Bentler, 1998) } \\
\text { Hu \& Bentler, 1999) }\end{array}$ & RMR & $<0.08$ & 0.022 \\
\hline (Hooper et al., 2008) & IFI & $>0.90$ & 0.932 \\
\hline (Hooper et al., 2008) & NFI & $>0.90$ & 0.988 \\
\hline Hu \& Bentler, 1999) & CFI & $>0.90$ & 0.993 \\
\hline
\end{tabular}

The results of mediation are shown in tables (4) and (5). The initial predictor variable is status consciousness, the outcome variables are consumer purchase intention and brad equity and the proposed mediating variable is brand associations. The direct effect between status consciousness and purchase intention is significant with $\mathrm{p}$ value $<0.05$. The indirect effect of status consciousness on purchase intention through brand associations came out to be 0.013 which is significant. It proves the meditational effect of brand associations between status consciousness and purchase intention. Hence it proves H4 i.e. brand associations mediate the relationship between status consciousness and purchase intention.

These results in table (5) suggest that the effects of status consciousness on consumer purchase intention transfer via brand associations i.e. if the brand associations in the mind of the customers are unique, strong and favorable then status conscious people will be more intended to purchase that brand because of the link node they have in their minds associated with the brand. These associations will help the customers to recall the brand at the time of purchase and will impact their purchase intention.

The second mediating effect of brand associations is examined between status consciousness and brand equity. The direct effect between status consciousness and brand equity is significant having $\mathrm{p}$ value < 0.05 . The indirect effect of status consciousness on brand equity through brand associations came out to be 0.018 which is significant. Hence it proved H5 i.e. brand associations mediates the relationship between status consciousness and brand equity. These results suggest that the effects of status consciousness on brand equity transfer via brand associations i.e. status conscious people will get the brand knowledge through the brand associations which help the customer to recall the brand because of the link node they have in their minds and based on this the image about the brand develops in their mind. This has an impact on brand equity because brand associations build the brand image and convey meaning about the brand to the customers thus developing a link between brand and customers.

The second proposed mediator is brand equity between brand associations and consumer purchase intention. The direct effect between brand associations and purchase intention is significant with $\mathrm{p}$ value < 0.05 . The indirect effect between of brand associations on purchase intention through brand equity came out to be 0.010 which is significant. Hence it proved H9 i.e. brand equity mediates the relationship between brand associations and purchase intention. These results suggest that the effects of brand associations on purchase intention transfer through brand equity i.e. if people have certain associations about a brand in their mind but they are also aware about the brand because of advertising campaigns and also they have a strong image in their mind about the brand then they can easily recognize that brand among other brands because of the brand awareness and strong brand image in their minds. Thus this will help them to differentiate a specific brand among other brands and will impact their purchase intention. 
Table (4) Results of Multiple Mediation Analysis (Direct Effect)

\begin{tabular}{|c|c|c|c|c|c|c|}
\hline \multicolumn{3}{|c|}{ Relations } & Estimate & S.E. & C.R. & Label \\
\hline BA & $<--$ & $\mathrm{SC}$ & .214 & .450 & 5.283 & $* * *$ \\
\hline $\mathrm{BE}$ & $<---$ & BA & .141 & .223 & 1.761 & .058 \\
\hline $\mathrm{BE}$ & $<---$ & $\mathrm{SC}$ & .229 & .326 & 8.894 & $* * *$ \\
\hline PI & $<---$ & BA & .212 & .443 & 4.983 & $* * *$ \\
\hline PI & $<---$ & $\mathrm{BE}$ & .170 & .282 & 2.066 & .039 \\
\hline PI & $<---$ & $\mathrm{SC}$ & .357 & .451 & 7.113 & $* * *$ \\
\hline
\end{tabular}

Significance level $<0.05$

Table (5) Results of Multiple Mediation Analysis (Indirect Effect)

\begin{tabular}{|l|l|l|l|}
\hline & SC & BA & BE \\
\hline BA & .000 & .000 & .000 \\
\hline BE & .018 & .000 & .000 \\
\hline PI & .013 & .010 & .000 \\
\hline
\end{tabular}

Significance level $<0.05$

\section{Direct relations}

\begin{tabular}{|l|l|l|l|l|}
\hline & Estimate & S.E. & C.R. & P \\
\hline PI <--- SC & .280 & .068 & 6.175 & $* * *$ \\
\hline
\end{tabular}




\begin{tabular}{|l|l|l|l|l|}
\hline BE <--- SC & .276 & .037 & 7.511 & $* * *$ \\
\hline PI <--- BA & .171 & .029 & 3.432 & $* * *$ \\
& & & & \\
\hline
\end{tabular}

\section{Discussion and Conclusion}

All the previous studies indicate that the need of status in people directly influence the brand associations, brand equity and consumer purchase intention (e.g. Eastman et al., 1999; O'Cass and Frost, 2002; Eastman and Clark et al., 2006; O'Cass and Siahtiri, 2012; Yoo et al., 2000; O'Cass and Lim, 2002). Existing literature also explains that brand equity directly influences consumer purchase intention (Dodds, Monroe and Grewal, 1991). The findings of this study support the already established studies and further provide support for the direct influence of status consciousness on consumer purchase intention and brand equity. The present study also explains that brand associations act as a mediator between status consciousness and consumer purchase intention and status consciousness and brand equity. It also suggests that brand equity acts as a mediator between brand association and consumer purchase intention.With the changing lifestyle the people's psychology and their consumption patterns are changing around the world. With the growth in economy the spending of people on luxurious products is also increasing. This trend is also observed in Pakistan. In the recent years, the lawn cloth has got the position of luxury product and for this many lawn brands have been launched by manufacturers with huge investments on advertising and promotional campaigns of these lawn brands. These brands are not only launching lawn in summer season but are also launching winter stuff in winter season. This boom in this sector has got extreme competition and all lawn brands are at war of competition. This vibrant and cut throat competition among these lawn brands have made them to come up with unique advertising and branding strategies in order to shine and dominate in the market. These brands launched their products with different designs and categories and at different premium prices. The very cheap lawn cloth has now become a premium and luxurious brand among female customers and they feel prestigious and superior from others after wearing these lawn brands. With immense demand of these eastern lawn brands, the manufacturers of these brands have opened their outlets in most of the cities in Pakistan where lots of female customers go for the lawn purchase.

These brands of lawn are targeting people with status needs they are investing huge amount in advertising their brands to create unique position of their brands in the minds of customers so that their customers could differentiated their brand from other brands because studies support that status conscious consumers consume those brands which are considered prestigious and superior brands in society (Eastman et al., 1999; O'Cass and Frost, 2002). This study sought to understand this need for status in people and its influence on brand equity and purchase intention of consumers. It has been established that this human need of status reflects on behavioral outcomes of customers such as purchase intention of consumer and brand equity.The need for status in consumers motivates them to purchase and acquire those brands which are having high status in society. This need for status acts as a motivator to consume stats laden brands. When a certain brand is positioned in their minds of the consumers as a status symbol, they intend to purchase these brands. Companies who are targeting status conscious people and who want to make their brands strong need to understand this need for status in people. Because this understanding of consumer status need will help them in positing their image in such a way that influence status seekers. Also this understanding will increase their brand equity because this will help them to develop strong brand association in the mind of the customers as these associations communicate meaning of the brand and help customers to differentiate a certain brand among other brands as these associations are stored as a link node in the mind of the customers. Also these associations if strong, favorable and unique will create a positive image of the brand in the mind of the customers. Also brand awareness and familiarity will create knowledge of the brand in the mind of the customers thus leading to build brand equity because this 
also help in creating differentiation of the brand among other brands as according to Keller (1993) brand equity us the differential effect that brand knowledge creates. This differentiation is very important because in today's world where there are unlimited brands, there is need to create unique position of a brand in consumers mind as Lim and O'Cass (2001) indicated that the most valuable assets and sources of differentiation for firms are their brands. Because this has an impact on consumer's brand selection and purchase intention. Also this will lead to an increase in brand equity which ultimately effect firm's profits as brands are the important contributors in the profits of firms.

Brand associations have very strong impact on consumer purchase intention and brand equity. If a certain brand is associated with luxury, prestige and status, it will create an image in the mind of the customer that using this brand will increase their status level and help them to signal their wealth to others. The brands associated with luxury then become status symbols in society. Status conscious people therefore want to acquire them so that they could show their luxury possessions to others. This will increase their willingness to purchase such brands. Similarly the brand associations create the image of the brands as status symbols by associating them with prestige and this impacts the brand name. Such brands thus become highly luxurious brand names to which status conscious people want to carry because in this way just the brand name communicates the status of the brand and the brand user. In this way status conscious people want to get associated with and become user of such brand names thus influencing and building strong brand equity.

\section{Managerial Implications and Future Research Directions}

Managers can understand that how consumer need for status impacts the behavior towards brands. They can understand the importance of brand association that how they should be created so that they can be fruitful in creating positive brand image in the mind of the customers because these are the brand knowledge that a consumer has in his/her memory as Managers of branded lawn can use these results to make more accurate predictions of purchase intentions and brand preference .Marketers can use the findings as an accurate tool to differentiate their market segments by ascertaining the consumer need for status and developing brands that are consistent with their need for status.It will also help in developing marketing and promotional strategies specifically designed to promote luxurious brands to increase consumer's purchase intention and brand. The results obtained will help the marketers by focusing on developing strong brand associations for luxurious brands for the status conscious consumers. This research was conducted in the outlets of branded lawn in the five major cities of Pakistan which are Karachi, Multan, Lahore, Islamabad and Faisalabad. Thus this research can be carried out in other cities of Pakistan and also in other countries of the world.This research is conducted on one product type. Same research can be performed on other types of precuts like gadgets, automobiles etc. also this research is limited to product only. Future research can be performed on the services sector.This research is conducted on the female consumers only. The same can be performed on male consumers as well. Also the same research can be performed at different age groups. The results of this study are according to the cultural values and economy of Pakistan. The results may vary from culture to culture and economy to economy in other countries. This study studies only two outcome variables that are brand equity and consumer purchase intention. Other outcome variables like brand loyalty, brand preference etc can also be studied in future research.

\section{References}

Aaker, D. A. (1991), Managing Brand Equity, The Free Press, New York, NY. Aaker, D. A. (1991), Building Strong Brands, The Free Press, New York, NY.

Agarwal, M. K., \& Rao, V. R. (1996). An empirical comparison of consumer-based measures of brand equity. Marketing letters, 7(3), 237-247.

Ajzen, I., \& Fishbein, M. (1980). Understanding attitudes and predicting social behavior.

Auty, S., \& Elliott, R. (1998). Fashion involvement, self-monitoring and the meaning of brands. Journal of Product \& Brand Management, 7(2), 109-123.

Belk, R. (1988). Possessions and self. John Wiley \& Sons, Ltd. 
Belk, R. W. (1989). Extended self and extending paradigmatic perspective. Journal of Consumer Research, 129-132.

Belén del Río, A., Vazquez, R., \& Iglesias, V. (2001). The effects of brand associations on consumer response. Journal of consumer marketing, 18(5), 410-425.

Bemmaor, A. C. (1995). Predicting behavior from intention-to-buy measures: The parametric case. Journal of Marketing Research, 176-191.

Biswas, A. (1992). The moderating role of brand familiarity in reference price perceptions. Journal of Business Research, 25(3), 251-262.

Blackwell, R. D., Miniard, P. W., \& Engel, J. F. (2001). Consumer behavior 9th.South-Western Thomas Learning. Mason, $\mathrm{OH}$.

Browne, M. W., \& Cudeck, R. (1993). Alternative ways of assessing model fit.Sage Focus Editions, 154, 136-136.

Bryne, B. (1998). Structural equation modeling with LISREL, PRELIS, AND SIMPLIS: Basic concepts, applications, and programming: Lawrence Erlbaum.

Burn, S. M. (2004). Groups: Theory and practice. Recording for the Blind \& Dyslexic.

Cass, A. O. (2001). Consumer self-monitoring, materialism and involvement in fashion clothing. Australasian Marketing Journal (AMJ), 9(1), 46-60.

Cheng, A and Chen, H. (2001), Using free associations to examine the relationship between the characteristics of brand associations and brand equity, Journal of Product and Brand Management, Vol. 10 Iss 7 pp. 439-451.

Clark, R. A., Zboja, J. J., \& Goldsmith, R. E. (2007). Status consumption and role-relaxed consumption: A tale of two retail consumers. Journal of Retailing and Consumer Services, 14(1), 45-59.

Cobb-Walgren, C. J., Ruble, C. A., \& Donthu, N. (1995). Brand equity, brand preference, and purchase intent. Journal of advertising, 24(3), 25-40.

Dodds, W. B., Monroe, K. B., \& Grewal, D. (1991). Effects of price, brand, and store information on buyers' product evaluations. Journal of marketing research, 307-319.

Eastman, J.K., Goldsmith, R.E., Flynn, L.R. (1999), Status Consumption in Consumer Behavior: Scale Development and Validation, Journal of Marketing Theory and Practice, Vol. 7, pp. 41-52.

Eastman K.K; and Eastman K.L (2011). Perception an of status and economy; Journal of Business and Economics Research 9(7), 9-20

Eng, T. Y., \& Bogaert, J. (2010). Psychological and cultural insights into consumption of luxury western brands in India. Journal of Customer Behaviour, 9(1), 55-75.

Erdem, T. (1998). An empirical analysis of umbrella branding. Journal of Marketing Research, 339-351.

Espejel, J., Fandos, C., \& Flavian, C. (2008). Consumer satisfaction: A key factor of consumer loyalty and buying intention of a PDO food product. British Food Journal, 110(9), 865-881.

Fan, X., Thompson, B., \& Wang, L. (1999). Effects of sample size, estimation methods, and model specification on structural equation modeling fit indexes.Structural Equation Modeling: A Multidisciplinary Journal, 6(1), 56-83.

Fishbein, M., \& Ajzen, I. (1975). Belief, attitude, intention and behavior: An introduction to theory and research.

Flynn, L. R., Goldsmith, R. E., \& Eastman, J. K. (1996). Opinion leaders and opinion seekers: Two new measurement scales. Journal of the Academy of Marketing Science, 24(2), 137-147.

Flynn, L. R., \& Goldsmith, R. E. (1999). A short, reliable measure of subjective knowledge. Journal of business research, 46(1), 57-66.

Gabriel, Y., \& Lang, T. (2006). The unmanageable consumer. Sage.

Goldsmith, R. E., Clark, R. A., \& Goldsmith, E. B. (2006). Extending the psychological profile of market mavenism. Journal of Consumer Behaviour,5(5), 411-419.

Goldsmith, R. E., Flynn, L. R., \& Clark, R. A. (2012). Materialistic, brand engaged and status consuming consumers and clothing behaviors. Journal of Fashion Marketing and Management: An International Journal, 16(1), 102-119.

Grace, D., \& O'Cass, A. (2002). Brand associations: looking through the eye of the beholder. Qualitative Market Research: An International Journal, 5(2), 96-111. 
Grnhaug, K. (1986). Subjective and objective measures of product knowledge contrasted. Advances in consumer research, 13, 67-71.

Gustafson, T. A. R. A., \& Chabot, B. R. I. A. N. (2007). Brand Awareness.Cornell Maple Bulletin, 105, $1-5$.

Gutman, J., \& Mills, M. K. (1982). Fashion life-style, self-concept, shopping orientation, and store patronage-an integrative analysis. Journal of Retailing,58(2), 64-86.

Han, Y. J., Nunes, J. C., \& Drèze, X. (2010). Signaling status with luxury goods: The role of brand prominence. Journal of Marketing, 74(4), 15-30.

Herbig, P., \& Milewicz, J. (1993). The relationship of reputation and credibility to brand success. Journal of Consumer Marketing, 10(3), 18-24.

Hooper, D., Coughlan, J., \& Mullen, M. (2008). Structural equation modelling: Guidelines for determining model fit. Articles, 2.

Husic, M., \& Cicic, M. (2009). Luxury consumption factors. Journal of Fashion Marketing and Management: An International Journal, 13(2), 231-245.

Hu, L. T., \& Bentler, P. M. (1998). Fit indices in covariance structure modeling: Sensitivity to underparameterized model misspecification. Psychological methods, 3(4), 424.

Hu, L. T., \& Bentler, P. M. (1999). Cutoff criteria for fit indexes in covariance structure analysis: Conventional criteria versus new alternatives. Structural equation modeling: a multidisciplinary journal, 6(1), 1-55.

Janiszewski, C., \& Van Osselaer, S. M. (2000). A connectionist model of brand-quality. Journal of Marketing Research, 37(3), 331-350.

Kamakura, W. A., \& Russell, G. J. (1993). Measuring brand value with scanner data. International Journal of Research in Marketing, 10(1), 9-22.

Keller, K. L. (1993), Conceptualizing, measuring and managing customer- based brand equity, Journal of Marketing, Vol. 57, January, pp. 1-22.

Kilsheimer, J.C. (1993), Status Consumption: The Development and Implications of a Scale Measuring the Motivation to Consumer for Status, a dissertation submitted to the Marketing Faculty at Florida State University, FL.

Krishnan, H. S. (1996). Characteristics of memory associations: A consumer-based brand equity perspective. International Journal of research in Marketing,13(4), 389-405.

Lassar, W., Mittal, B. Sharma, A. (1995), Measuring customer-based brand equity. Journal of Consumer Marketing, Vol. 12 No. 4, pp. 11-19.

Lades, W. M., \& Posner, R. A. (1987). Trademark law: an economic perspective. Journal of Law and Economics, 265-309.

Leiss, W., Kline, S., \& Jhally, S. (1990). Social communication in advertising: persons, products \& images of well-being. Psychology Press.

Lertwannawit, A., \& Mandhachitara, R. (2012). Interpersonal effects on fashion consciousness and status consumption moderated by materialism in metropolitan men. Journal of Business Research, 65(10), 1408-1416.

Lim K and O'Cass A (2001), Consumer brand classifications: an assessment of culture-of-origin versus country-of-origin, Journal of Product \& Brand Management, Vol 10,p 120-136.

Lin, L. Y., \& Lu, C. Y. (2010). The influence of corporate image, relationship marketing, and trust on purchase intention: the moderating effects of word-of-mouth. Tourism Review, 65(3), 16-34.

McNeal, J. U., \& Zeren, L. M. (1981). Brand name and selection for consumer products. MSU Business Topics, 29(2), 35-39.

Morris, B. (1996), The brand's the thing, Fortune, Vol. 133 No. 4, pp. 28-38.

O'Cass, A. (2000). An assessment of consumers product, purchase decision, advertising and consumption involvement in fashion clothing. Journal of Economic Psychology, 21(5), 545-576.

O'Cass, A. and Lim, K. (2001). The Influence of Brand Associations on Brand Preference and Purchase Intention: An Asian Perspective on Brand Associations, Journal of International Consumer Marketing, Vol. 14 (2/3).

O'cass, A., \& Frost, H. (2002). Status brands: examining the effects of non-product-related brand 
associations on status and conspicuous consumption. Journal of product \& brand management, 11(2), 67-88.

O'Cass, A., \& Lim, K. (2002). Toward understanding the young consumer's brand associations and ethnocentrism in the lion's port. Psychology \& Marketing, 19(9), 759-775

O'Cass, A. (2004). Fashion clothing consumption: antecedents and consequences of fashion clothing involvement. European Journal of Marketing,38(7), 869-882.

O'cass, A., \& McEwen, H. (2004). Exploring consumer status and conspicuous consumption. Journal of Consumer Behaviour, 4(1), 25-39.

O'Cass, A. and Siahtir, V. (2014). Are young adult Chinese status and fashion brand conscious?, Journal of Fashion Marketing and Management, Vol. 18 Iss 3 pp. 248-300.

Onkvisit, S., \& Shaw, J. (1987). Self-concept and image congruence: Some research and managerial implications. Journal of Consumer Marketing, 4(1), 13-23.

Packard, V. (1959). The Status Seekers. New York, McGraw Hill, New York.

Park, C. S., and Srinivasan, V. (1994). A survey based method for measuring and understanding brand equity and its extendibility. Journal of marketing research, 271-288.

Pitta, A. D. and Katsanis, P. L. (1995), Understanding brand equity for successful brand extensions, Journal of Consumer Marketing, Vol. 12 Iss 4 pp. 51-64.

Malik, M. E., Ghafoor, M. M., Iqbal, H. K., Ali, Q., Hunbal, H., Noman, M., \& Ahmed, B. (2013). Impact of brand image and advertisement on consumer buying behavior. World Applied Sciences Journal, 23(1), 117-122.

Marsh, H. W., Balla, J. R., \& McDonald, R. P. (1988). Goodness-of-fit indexes in confirmatory factor analysis: The effect of sample size. Psychological bulletin, 103(3), 391.

Michaelidou, N., \& Dibb, S. (2006). Product involvement: an application in clothing. Journal of Consumer Behaviour, 5(5), 442-453.

Nunnally, J. C. Bernstein. IH (1994). Psychometric theory.

Raju, P. S., Lonial, S. C., \& Mangold, W. G. (1995). Differential effects of subjective knowledge, objective knowledge, and usage experience on decision making: An exploratory investigation. Journal of consumer psychology, 4(2), 153-180.

Schumacker, R. E., \& Lomax, R. G. (2004). A beginner's guide to structural equation modeling. Psychology Press.

Shao, C. Y., Baker, J. A., \& Wagner, J. (2004). The effects of appropriateness of service contact personnel dress on customer expectations of service quality and purchase intention: The moderating influences of involvement and gender.Journal of Business Research, 57(10), 11641176.

Shimp, T. A. (1993). Promotion management \& marketing communications.

Shocker, A. D., Srivastava, R. K., \& Ruekert, R. W. (1994). Challenges and opportunities facing brand management: An introduction to the special issue.Journal of Marketing Research, 149-158.

Sirgy, M. J. (1982). Self-concept in consumer behavior: A critical review.Journal of consumer research, 287-300.

Sirgy, M. J., Grewal, D., Mangleburg, T. F., Park, J. O., Chon, K. S., Claiborne, C. B., ... \& Berkman, H. (1997). Assessing the predictive validity of two methods of measuring self-image congruence. Journal of the academy of marketing science, 25(3), 229-241.

Smith, R. E., \& Swinyard, W. R. (1983). Attitude-behavior consistency: The impact of product trial versus advertising. Journal of Marketing Research, 257-267.

Solomon, M. R. (1999). The value of status and the status of value. Consumer value: A framework for analysis and research, 63-84.

Srivastava, R. K., \& Shocker, A. D. (1991). Brand equity: a perspective on its meaning and measurement. Marketing Science Institute.

Steiger, J. H. (1990). Structural model evaluation and modification: An interval estimation approach. Multivariate behavioral research, 25(2), 173-180.

Stokes, R. C. (1974). The effects of price, package design, and brand familiarity on perceived quality (Doctoral dissertation, ProQuest Information \& Learning). 
Summers, J. O. (1970). The identity of women's clothing fashion opinion leaders. Journal of Marketing Research, 178-185.

Truong, Y., McColl, R., \& Kitchen, P. J. (2010). Uncovering the relationships between aspirations and luxury brand preference. Journal of Product \& Brand Management, 19(5), 346-355.

Ullman, J. B. (2006). Structural equation modeling: Reviewing the basics and moving forward. Journal of personality assessment, 87(1), 35-50.

Veblen T. (1899). The Theory of the Leisure Class

Warshaw, P. R. (1980). A new model for predicting behavioral intentions: An alternative to Fishbein. Journal of Marketing Research, 153-172.

Wong, N. Y., \& Ahuvia, A. C. (1998). Personal taste and family face: Luxury consumption in Confucian and Western societies. Psychology and Marketing,15(5), 423-441.

Yoo, B., Donthu, N., \& Lee, S. (2000). An examination of selected marketing mix elements and brand equity. Journal of the academy of marketing science,28(2), 195-211.

Zinkhan, G. M., \& Prenshaw, P. J. (1994). Good life images and brand name associations: Evidence from Asia, America, and Europe. Advances in consumer research, 21, 496-496 
